The Agriculturists 14(1): 122-133 (2016) ISSN 2304-7321 (Online), ISSN 1729-5211 (Print)

A Scientific Journal of Krishi Foundation

Indexed Journal

Impact Factor: 0.402 (GIF, 2014)

\title{
Use of RAPD Markers to Analyze Genetic Variability of Introgressed Brassica Lines
}

\author{
Md. Harun-Or-Rashid ${ }^{1}$, Md. Shafikur Rahman ${ }^{2}$, Sudhir Chandra Nath ${ }^{1}$, \\ S.S.R.M. Mahe Alam Sorwar ${ }^{1}$ and Md. Tanvir Ahmed ${ }^{1}$ \\ ${ }^{1}$ Seed and Agro Enterprise, Bangladesh Rural Advancement Committee (BRAC) \\ ${ }^{2}$ Department of Biotechnology, Patuakhali Science and Technology University, Bangladesh \\ *Corresponding author and Email: harunbt@yahoo.com, harun.rashid@brac.net
}

Received: 28 March $2016 \quad$ Accepted: 12 June 2016

\begin{abstract}
Seven individuals of introgressed Brassica lines (Binasarisha-5/Daulot) and two of their parental lines were used for this study to estimate genetic variability using three randomly amplified polymorphic DNA (RAPD) markers (61AB10G1, 72AB10G12 and 73AB10T13). A total of 23 clear bands were scored, of which $21(91.30 \%)$ bands were proved to be polymorphic. The highest proportion of polymorphic loci and gene diversity values were $43.48 \%$ and 0.187 , respectively in the line five of Binasarisha-5/Daulot. The lower proportion of polymorphic loci and gene diversity values were $8.70 \%$ and $0.034 ; 8.70 \%$ and 0.026 in the line seven of the cross and one parent, Daulot, respectively. The coefficient of gene differentiation $\left(\mathrm{G}_{\mathrm{st}}\right)$ and gene flow $\left(\mathrm{N}_{\mathrm{m}}\right)$ values were 0.677 and 0.237 , found respectively from the Popgene analysis. Result of cluster analysis indicated that the nine accessions were capable of being classified into two major groups - one consists of only one parent Daulot (Brassica juncea) while another consists of Binasarisha-5 (Brassica napus) and all introgressed lines of $\mathrm{C}_{6}$ generation (treated with colchicine in $\mathrm{C}_{1}$ generation) resulted from the cross $B$. napus and $B$. juncea. Introgressed line seven and Binasarisha-5 showed the lowest genetic distance of 0.077. Higher similarity was found between Binasarisha-5 and introgressed progenies. Introgressed line one and Daulot showed the highest genetic distance of 0.709 , which can be used as germplasm for breeding program that aim to improve Brassica. It was concluded that RAPD markers can be used for the study of molecular characterization and diversity in Brassica.
\end{abstract}

Keywords: RAPD, Genetic Variability, Introgressed Brassica

\section{Introduction}

The genus Brassica includes two major groups of crop plants viz. the vegetable group and the oilseed group. The vegetable group includes the species $B$. oleracea $(\mathrm{CC}, 2 \mathrm{n}=18)$ while the oilseed group includes five major species viz. $B$. nigra Koch (BB, $2 \mathrm{n}=16), B$. campestris $\mathrm{L}$. (AA, $2 \mathrm{n}=20), B$. carinata Braun (BBCC, $2 \mathrm{n}=34), B$. juncea Czern and Coss (AABB, $2 \mathrm{n}=36)$ and $B$. napus L. (AACC, 2n=38). In Brassica, the three diploid species Brassica rapa (AA), Brassica nigra (BB), Brassica oleracea (CC) are elemental to the species of $B$. juncea (AABB), $B$. carinata (BBCC) and B. napus (AACC), which are amphidiploid (Prakash and Hinata, 1980). Among the oleiferous Brassica species the varieties of $B$. campestris and $B$. napus are commonly known as rapeseed, while those of $B$. nigra, B. carinata and $B$. juncea as mustard 
(Yarnell, 1956). RAPD technique requires only the presence of a single 'randomly chosen' oligonucleotide. Individual RAPD primers are able to hybridize to several hundred sites within the target DNA. A relatively small number of primers can be used to generate a very large number of fragments which are usually generated from different regions of the genome and hence multiple loci may be examined very quickly (Edwards, 1998). RAPD technique is widely applicable for analysis of most organisms because universal sets of primers are used without any need for primer sequence information (Hallden et al., 1996, Hasan and Raihan, 2014). This marker system is being used in many different applications involving the detection of DNA sequence polymerisms, mapping different types of populations (Carlson et al., 1991; Reiter et al., 1992), isolation of markers linked to various traits or specific targeted intervals (Giovannoni et al., 1991; Michelmore et al., 1991) and applications such as variety identification and analysis of parentage (Tinker et al., 1993; Mailer et al., 1994, Hasan and Raihan, 2015). In recent studies on Brassica crops using molecular markers, RAPDs have been widely used in variety identification (Qiao et al., 1998), analysis of genetic relatedness (Warwick et al., 2001; Geraci et al., 2001; Matsui et al., 2002), genetic diversity analysis (Yuan et al., 2004; Dan et al., 2003; Machao et al., 2003; Rabbani et al., 1998), estimation of genetic variations (Das et al., 1998), measurement of genetic distance (Furguth et al., 2000), DNA fingerprinting (Duan et al., 2002) and genetic mapping (Sharma et al., 2002). The general objective of this study was to create a base for genetic analysis of the cross product and their parents of Brassica using Random Amplified Polymorphic DNA (RAPD) markers. Some works based on phenotypic characters have been performed. However, 'characterizing the $\mathrm{C}_{6}$ population of Brassica hybrids along with their parents at morphological traits level' and 'determining the genetic variation among the introgressed progenies and their parents' were carried out to attain the specific aims.

\section{Materials and Methods}

\subsection{Plant material}

Twenty introgressed progenies $\left(\mathrm{C}_{6}\right.$ generation) were developed from the cross between Binasarisha-5 (B. napus) and Daulot (B. juncea). The seeds of Daulot, introgressed progeny lines and Binasarisha-5 were collected from the Department of Genetics and Plant Breeding of Bangladesh Agricultural University (BAU) and Bangladesh Institute of Nuclear Agriculture, Mymensingh, Bangladesh, respectively. Also the present research was conducted in Department of Genetics and Plant Breeding of BAU during the year 2006-2007.

\subsection{DNA extraction}

Approximately $2 \mathrm{~cm}$ of fresh leaf tissues were cut into small pieces in $1.5 \mathrm{ml}$ eppendorf tube and digested with extraction buffer $(50 \mathrm{mM}$ Tris$\mathrm{HCl}, \mathrm{pH}$ 8.0, $300 \mathrm{mM} \mathrm{NaCl}, 25 \mathrm{mM}$ EDTA, $1 \%$ Sodium Dodecyl Sulphate). DNA was purified by successive extraction with phenol:chloroform:isoamyl alcohol (25:24:1; v:v:v). DNA was precipitated with $800 \mu \mathrm{l}$ of absolute ethanol where DNA became visible as white strands by flicking the tube several times with fingers. DNA was pelleted by centrifugation and reprecipitation of the DNA solution was done by adding $400 \mu \mathrm{l}$ of $70 \%$ ethanol with $20 \mu \mathrm{l} 3 \mathrm{M}$ sodium acetate and pelleted by centrifugation. The pellets were then air dried and dissolved in $50 \mu$ l of TE buffer (10 $\mathrm{mM}$ Tris. $\mathrm{HCl}, 1 \mathrm{mM}$ EDTA, $\mathrm{pH}$ 8.0). DNA quality was checked by electrophoresis in $1 \%$ agarose gel and quantified using a spectrophotometer at $260 \mathrm{~nm}$ wave length (Spectronic $^{\circledR}$ GENESIS $^{\mathrm{TM}}$ ).

\subsection{Primer selection}

Eleven primers (63AB10A3, 68AB10A8, 62AB10C2, 69AB10C9, 70AB10C10, 61AB10G1' 64AB10G4, 66AB10G6, 71AB10G11, 72AB10G12, 73AB10T13) random sequence were screened on a sub-sample of two randomly chosen individuals from two different 
varieties to evaluate their suitability for amplification of the DNA sequences, which could be scored accurately. Primers were evaluated based on intensity of bands, consistency within individual, presence of smearing and potential for population discrimination. The details of the primers are given in Table 1. A final subset of three primers (61AB10G1, 72AB10G12 and 73AB10T13) exhibiting good quality banding patterns and sufficient variability were selected for further analysis.

\subsection{DNA amplification by PCR and electrophoresis}

The amplification conditions were based on Williams et al. (1990) with some modification. PCR reactions were performed on each DNA sample in a $10 \mu \mathrm{l}$ reaction mix containing $1 \mu \mathrm{l}$ of 10X Ampli Taq polymerase buffer, $2 \mu$ of 10 $\mu \mathrm{M}$ primer, $1 \mu \mathrm{l}$ of $250 \mu \mathrm{M}$ dNTPs, 1 unit of Ampli Taq DNA polymerase (Bangalore Genei, India) and $100 \mathrm{ng}(4 \mu \mathrm{l})$ genomic DNA and a suitable amount of sterile deionized water. The PCR buffer, dNTPs, primer and DNA samples solutions were thawed from frozen stocks, mixed by vortexing and kept on ice. DNA templates were pipetted first into PCR tubes compatible with the thermocycler used $(0.2 \mathrm{ml})$. A pre-mix was then prepared in the course of the following order: reaction buffer, primer, dNTPs, sterile distilled water. Taq polymerase enzyme was then added to the pre-mix. The pre-mix was then mixed up well and aliquoted into the tubes that already contain DNA. The tubes were then sealed and placed in a thermocycler and the cycling was started immediately. DNA amplification was performed in an oil-free thermal cycler (Master Cycler Gradient, Eppendorf). The reaction mix was preheated at $94^{\circ} \mathrm{C}$ for 3 minutes followed by 45 cycles of 1 min denaturation at $94^{\circ} \mathrm{C}, 1 \mathrm{~min}$ annealing at $37^{\circ} \mathrm{C}$ and elongation or extension at $72^{\circ} \mathrm{C}$ for 2 minutes. After the last cycle, a final step of 7 minutes at $72^{\circ} \mathrm{C}$ was added to allow complete extension of all amplified fragments. After completion of cycling program, reactions were held at $4^{\circ} \mathrm{C}$. PCR products from each sample were confirmed by running $1.4 \%$ agarose gel containing $6 \mu \mathrm{l}$ Ethidium bromide in $1 \mathrm{X}$ TBE buffer at $120 \mathrm{~V}$ for $1 \mathrm{hr}$. Loading dye $(2.5 \mu \mathrm{l})$ was added to the PCR products and loaded in the wells. Molecular weight marker DNA (100bp DNA ladder) was also loaded on either side of the gel. RAPD bands were observed under ultra violet light on a transilluminator (Bio-Rad Gel Doc) and documented by taking photograph using a Gel documentation system.

\subsection{RAPD data analysis}

All distinct bands or fragments (RAPD markers) were thereby given identification numbers according to their position on gel and scored visually on the basis of their presence (1) or absence (0), separately for each individual and each primer. The scores obtained using all primers in the RAPD analysis were then pooled to create a single data matrix. This was used to estimate polymorphic loci (Nei's, 1972), gene diversity, population differentiation $\left(\mathrm{F}_{\mathrm{st}}\right)$, gene flow $\left(\mathrm{N}_{\mathrm{m}}\right)$, genetic distance (D) and to construct a UPGMA (Unweighted Pair Group Method of Arithmetic Means) dendrogram among populations using a computer program, POPGENE (Version 1.31) (Yeh et al., 1999). The similarity index values (SI) between the RAPD profiles of any two individuals on the same gel were calculated from RAPD markers according to the following formula: Similarity index $(\mathrm{SI})=2 \mathrm{~N}_{\mathrm{xy}} / \mathrm{N}_{\mathrm{x}}+\mathrm{N}_{\mathrm{y}}$ Where, $\mathrm{N}_{\mathrm{xy}}$ is the total number of RAPD bands shared by individuals $x$ and y (Chapco et al., 1992) respectively, and $\mathrm{N}_{\mathrm{x}}$ and $\mathrm{N}_{\mathrm{y}}$ are the number of bands in individual $\mathrm{x}$ and $y$, respectively. The SI values range from 0 to 1. When SI=1.0, the two DNA profiles are identical and when SI is 0.0, there are no common bands between the two profiles. Population similarity within individuals $\left(\mathrm{S}_{\mathrm{i}}\right)$ was calculated as the average of SI across all possible comparisons between individuals within a population. Population similarity between individuals $\left(S_{i j}\right)$ was calculated as the average similarity between each paired individuals of population $\mathrm{i}$ and $\mathrm{j}$ (Lynch, 1991). 


\section{Results and Discussion}

Seven introgressed individuals from $\mathrm{C}_{6}$ materials (Binasarisha-5/Daulat) and two individuals of their parent including species of $B$. nupus and $B$. juncea were analyzed as a group and a total of 23 RAPD bands were scored. Each of the 11 primers varied greatly in their ability to resolve variability among the accessions. Eleven decamer primers were initially screened for their ability to produce polymorphic patterns and three decamer primers $(61 \mathrm{AB} 10 \mathrm{G} 1,72 \mathrm{AB} 10 \mathrm{G} 12$ and 73AB10T13) which gave reproducible and distinct polymorphic amplified products were selected for evaluation of diversity across all the accessions. A total of 21 polymorphic amplification products were obtained by using these arbitrary primers. The size of the amplification products ranged from 246-3683bp (Table 1). The selected three primers produced comparatively maximum number of high intensity band with minimal smearing. The three primers showing good technical resolution and sufficient variation among different samples produced a total of 23 RAPD markers of which $21(91.3 \%)$ were considered as polymorphic (either occurring in or absent in less than 23 of all individuals). The primer 61AB10G1 amplified maximum number of polymorphic bands $(42.86 \%)$ and the primer $72 \mathrm{AB} 10 \mathrm{G} 12$ generated $23.80 \%$ polymorphic bands which were minimum in number. The polymorphic amplification bands ranged from 5-9 and averaged to 7 (Table 1).The banding patterns of seven individuals from $\mathrm{C}_{6}$ materials (Binasarisha-5/Daulat) and their two parents of Brassica sp. using the primers 61AB10G1, $72 \mathrm{AB} 10 \mathrm{G} 12$ and $73 \mathrm{AB} 10 \mathrm{~T} 13$ are shown in using primers $61 \mathrm{AB} 10 \mathrm{G} 1,72 \mathrm{AB} 10 \mathrm{G} 12$ and 73AB10T13, the banding patterns of seven individuals from $\mathrm{C}_{6}$ materials (Binasarisha5/Daulat) and their parents of Brassica are shown in Figure 1-3.

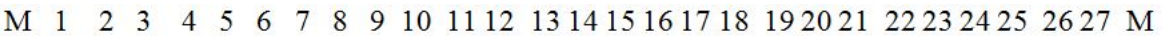

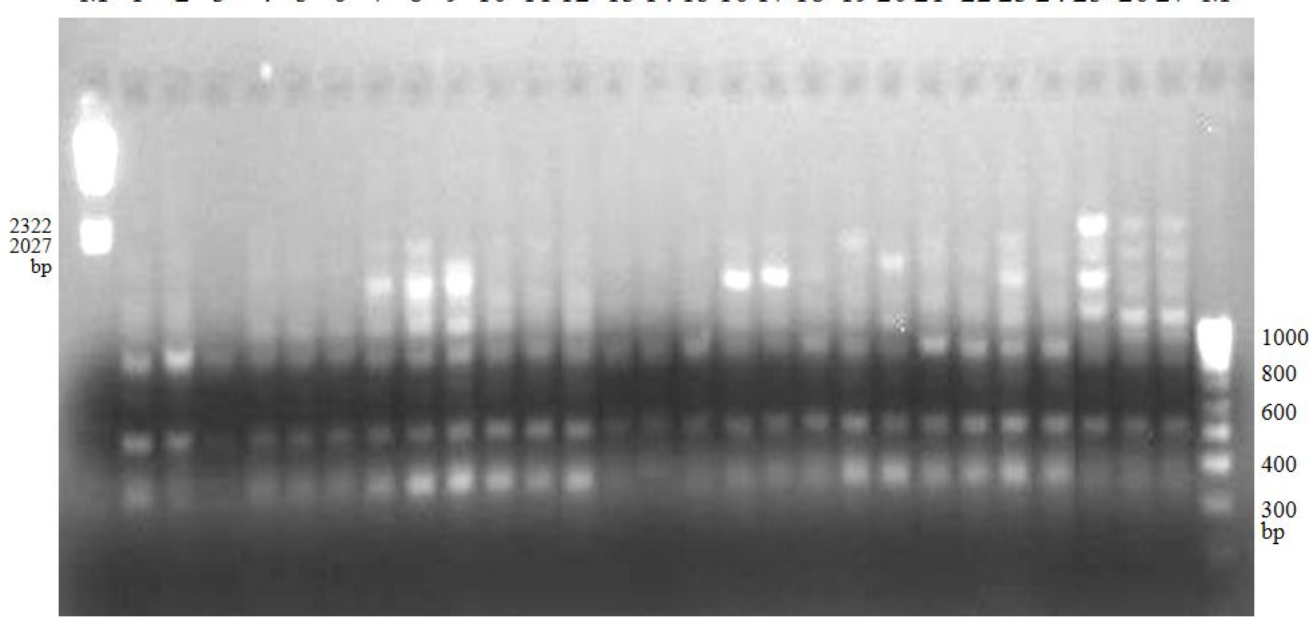

Figure 1. RAPD profiles of seven introgressed progeny lines and two parents using primer 61AB10G1. Lane 1-21: Binasarisha-5 / Daulot, lane 22-24: Binasarisha-5 and lane 25-27: Daulot. Ms: Molecular weight markers ( $\lambda$ DNA Hind III digest/100 bp DNA ladder) 


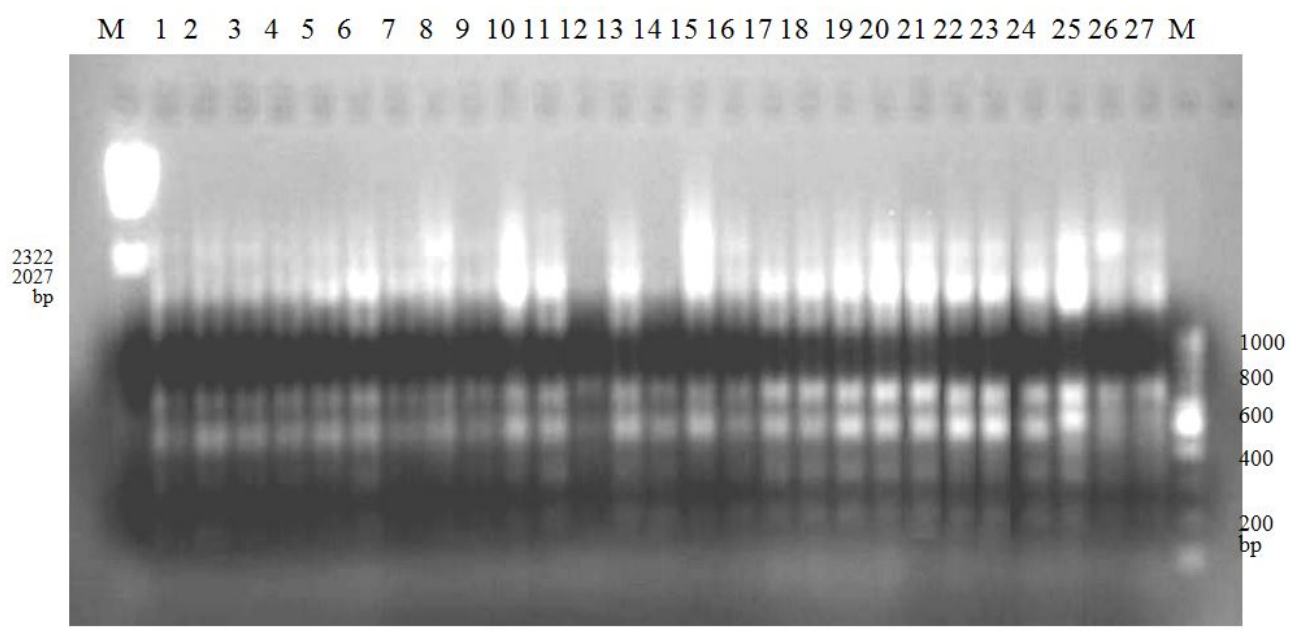

Figure 2. RAPD profiles of seven introgressed progeny lines and two parents using primer 72AB10G12. Lane 1-21: Binasarisha-5 / Daulot, lane 22-24: Binasarisha-5 and lane 2527: Daulot. Ms: Molecular weight markers ( $\lambda$ DNA Hind III digest/100 bp DNA ladder)

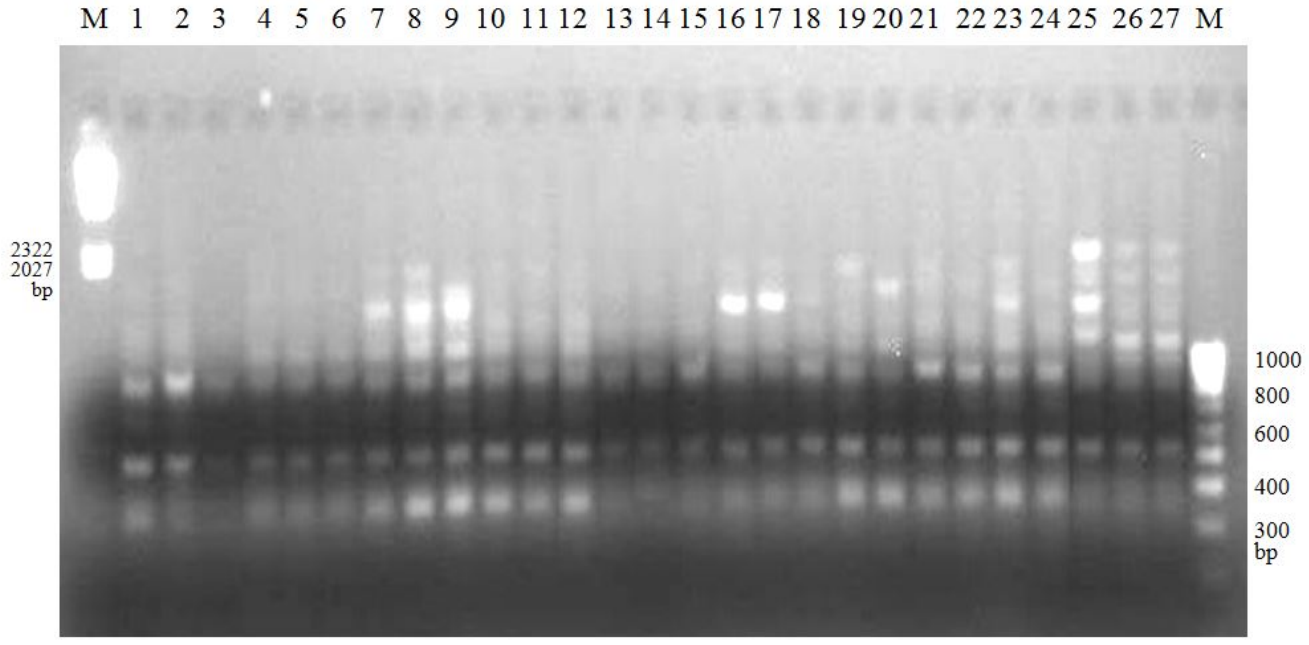

Figure 3. RAPD profiles of seven introgressed progeny lines and two parents using primer 73AB10T13Lane 1-21: Binasarisha-5 / Daulot, lane 22-24: Binasarisha-5 and lane 25-27: Daulot. Ms: Molecular weight markers ( $\lambda$ DNA Hind III digest/100 bp DNA ladder)

Intra-variety similarity indices $\left(\mathrm{S}_{\mathrm{i}}\right)$ were higher (ranged from $78.22-97.21 \%$ ) than inter variety similarity indices $\left(\mathrm{S}_{\mathrm{ij}}\right)$ (ranging from 44.75 $90.85 \%$ ) indicating high genetic variation. For the population of introgressed line seven
(97.21\%) and Daulot (96.26\%), intra-varietal similarity indices were found to be higher than the other introgressed progeny lines and Binasarisha-5. On the other hand, population of introgressed line five showed the lowest 
similarity indices $(78.22 \%)$. Inter-varietal means the pair-wise similarity indices $\left(\mathrm{S}_{\mathrm{ij}}\right)$ ranged from (44.75-90.85\%). The highest similarity indices of $90.85 \%$ was found between introgressed line seven - Binasarisha-5, while introgressed line one - Daulot showed least inter-variety similarity indices $44.75 \%$. Band sharing based intravarietal similarity indices were higher (Average $97.21 \%$ ) than inter-varietal similarity indices $(90.85 \%)$.

The highest number and proportion of polymorphic loci was found in the introgressed progeny line five, which were 10 and $43.48 \%$, respectively, whereas lower values $(2$ and $8.70 \%$ ) of these traits were recorded in both the varieties Daulot and introgressed progeny line seven (Table 3). However, the highest and lowest Nei's (1972) gene diversity values were found in introgressed line five and Daulot, respectively.

The Nei's original measures of genetic distance (Nei, 1972) were calculated from combined data sets for 3 primers ranging from 0.077 to 0.709 . The genetic distance value between introgressed progeny line of (Binasarisha-5/Daulot) 1 and variety Daulot was found to be the highest (0.709). This high genetic similarity supports the theory that they share a common origin. The lowest genetic distance (0.077) was found in introgressed progeny lines pair of two and four (Table 4).

Table 1. Selected primers and genetic variations of introgressed Brassica lines in RAPD analysis

\begin{tabular}{lllll}
\hline Primer codes & $\begin{array}{l}\text { Sequences } \\
\left(5^{\prime}-3^{\prime}\right)\end{array}$ & $\begin{array}{l}\text { Total number of } \\
\text { bands scored }\end{array}$ & $\begin{array}{l}\text { Size range } \\
(\mathrm{bp})\end{array}$ & $\begin{array}{l}\text { Number of } \\
\text { polymorphic bands }\end{array}$ \\
\hline 61AB10G1 & ACCGCGAAGG & 9 & $246-2493$ & 9 \\
72AB10G12 & AGGGCGTAAG & 7 & $250-2478$ & 5 \\
73AB10T13 & CTGGGGACTT & 7 & $359-3683$ & 7 \\
\hline Total & & 23 & & 21 \\
\hline
\end{tabular}

Table 2. Summary of band sharing based similarity indices within and between individuals of nine different Brassica lines A. Intra-varietal similarity indices $\left(\mathrm{S}_{\mathrm{i}}\right)$

\begin{tabular}{lllll}
\hline $\begin{array}{l}\text { Introgressed progeny } \\
\text { Variety }\end{array}$ & lines/ & \multicolumn{2}{l}{ Band sharing values (\%) } & \\
\cline { 2 - 5 } & 61AB10G1 & 72AB10G12 & 73AB10T13 & Average \\
\hline (Binasarisha-5/Daulot)1 & 62.24 & 100 & 77.77 & 80.00 \\
(Binasarisha-5/Daulot)2 & 90.47 & 86.66 & 100 & 92.37 \\
(Binasarisha-5/Daulot)3 & 91.64 & 100 & 93.93 & 95.19 \\
(Binasarisha-5/Daulot)4 & 91.66 & 62.24 & 100 & 84.63 \\
(Binasarisha-5/Daulot)5 & 74.53 & 73.48 & 86.66 & 78.22 \\
(Binasarisha-5/Daulot)6 & 81.67 & 88.88 & 93.93 & 88.16 \\
(Binasarisha-5/Daulot)7 & 91.64 & 100 & 100 & 97.21 \\
Binasarisha-5 & 84.91 & 90.90 & 86.66 & 87.49 \\
Daulot & 94.86 & 93.93 & 100 & 96.26 \\
\hline
\end{tabular}




\section{B. Inter-varietal similarity indices $\left(S_{i j}\right)$}

\begin{tabular}{|c|c|c|c|c|}
\hline \multirow{2}{*}{$\begin{array}{l}\text { Variety and introgressed progeny } \\
\text { lines pair }\end{array}$} & \multicolumn{4}{|c|}{ Band sharing values (\%) } \\
\hline & 61AB10G1 & 72AB10G12 & 73AB10T13 & Average \\
\hline $\begin{array}{l}\text { (Binasarisha-5/Daulot)1- } \\
\text { (Binasarisha-5/Daulot)2 }\end{array}$ & 74.47 & 93.33 & 88.88 & 85.56 \\
\hline $\begin{array}{l}\text { (Binasarisha-5/Daulot)1- } \\
\text { (Binasarisha-5/Daulot)3 }\end{array}$ & 69.99 & 100.0 & 75.53 & 81.84 \\
\hline $\begin{array}{l}\text { (Binasarisha-5/Daulot)1- } \\
\text { (Binasarisha-5/Daulot)4 } \\
\text { (Binasarisha-5/Daulot)1- }\end{array}$ & 69.99 & 73.12 & 88.88 & 77.33 \\
\hline $\begin{array}{l}\text { (Binasarisha-5/Daulot)5 } \\
\text { (Binasarisha-5/Daulot)1- }\end{array}$ & 67.45 & 82.56 & 68.67 & 72.89 \\
\hline $\begin{array}{l}\text { (Binasarisha-5/Daulot)6 } \\
\text { (Binasarisha-5/Daulot)1- }\end{array}$ & 66.66 & 78.10 & 72.76 & 72.50 \\
\hline $\begin{array}{l}\text { (Binasarisha-5/Daulot)7 } \\
\text { (Binasarisha-5/Daulot)1- }\end{array}$ & 71.70 & 72.72 & 78.30 & 74.24 \\
\hline Binasarisha-5 & 67.84 & 72.72 & 82.59 & 74.38 \\
\hline $\begin{array}{l}\text { (Binasarisha-5/Daulot)1- Daulot } \\
\text { (Binasarisha-5/Daulot)2- }\end{array}$ & 00.00 & 85.92 & 48.33 & 44.75 \\
\hline $\begin{array}{l}\text { (Binasarisha-5/Daulot)3 } \\
\text { (Binasarisha-5/Daulot)2- }\end{array}$ & 89.26 & 93.33 & 85.92 & 89.50 \\
\hline $\begin{array}{l}\text { (Binasarisha-5/Daulot)4 } \\
\text { (Binasarisha-5/Daulot)2- }\end{array}$ & 89.07 & 75.67 & 100.0 & 88.24 \\
\hline $\begin{array}{l}\text { (Binasarisha-5/Daulot)5 } \\
\text { (Binasarisha-5/Daulot)2- }\end{array}$ & 81.65 & 80.86 & 73.00 & 78.50 \\
\hline $\begin{array}{l}\text { (Binasarisha-5/Daulot)6 } \\
\text { (Binasarisha-5/Daulot)2- }\end{array}$ & 84.10 & 80.86 & 82.96 & 82.64 \\
\hline $\begin{array}{l}\text { (Binasarisha-5/Daulot)7 } \\
\text { (Binasarisha-5/Daulot)2- }\end{array}$ & 85.85 & 79.24 & 88.88 & 84.65 \\
\hline Binasarisha-5 & 78.61 & 79.24 & 93.33 & 83.72 \\
\hline $\begin{array}{l}\text { (Binasarisha-5/Daulot)2-Daulot } \\
\text { (Binasarisha-5/Daulot)3- }\end{array}$ & 71.23 & 86.73 & 60.00 & 72.65 \\
\hline $\begin{array}{l}\text { (Binasarisha-5/Daulot)4 } \\
\text { (Binasarisha-5/Daulot)3- }\end{array}$ & 94.41 & 73.12 & 85.92 & 84.48 \\
\hline $\begin{array}{l}\text { (Binasarisha-5/Daulot)5 } \\
\text { (Binasarisha-5/Daulot)3- }\end{array}$ & 84.90 & 82.57 & 60.58 & 76.01 \\
\hline $\begin{array}{l}\text { (Binasarisha-5/Daulot)6 } \\
\text { (Binasarisha-5/Daulot)3- }\end{array}$ & 82.19 & 78.10 & 94.94 & 85.07 \\
\hline $\begin{array}{l}\text { (Binasarisha-5/Daulot)7 } \\
\text { (Binasarisha-5/Daulot)3- }\end{array}$ & 92.83 & 72.72 & 83.63 & 83.06 \\
\hline Binasarisha-5 & 82.98 & 72.72 & 88.59 & 81.43 \\
\hline $\begin{array}{l}\text { (Binasarisha-5/Daulot)3- Daulot } \\
\text { (Binasarisha-5/Daulot)4- }\end{array}$ & 80.46 & 85.92 & 76.25 & 80.87 \\
\hline $\begin{array}{l}\text { (Binasarisha-5/Daulot)5 } \\
\text { (Binasarisha-5/Daulot)4- }\end{array}$ & 84.95 & 72.83 & 73.00 & 76.92 \\
\hline (Binasarisha-5/Daulot)6 & 81.89 & 76.29 & 82.96 & 80.38 \\
\hline
\end{tabular}




\begin{tabular}{|c|c|c|c|c|}
\hline \\
\hline $\begin{array}{l}\text { (Binasarisha-5/Daulot)4- } \\
\text { (Binasarisha-5/Daulot)7 } \\
\text { (Binasarisha-5/Daulot)4- }\end{array}$ & 92.93 & 78.91 & 88.88 & 86.90 \\
\hline Binasarisha-5 & 83.12 & 78.91 & 93.33 & 85.12 \\
\hline $\begin{array}{l}\text { (Binasarisha-5/Daulot)4- Daulot } \\
\text { (Binasarisha-5/Daulot)5- }\end{array}$ & 80.62 & 76.48 & 60.00 & 72.36 \\
\hline $\begin{array}{l}\text { (Binasarisha-5/Daulot)6 } \\
\text { (Binasarisha-5/Daulot)5- }\end{array}$ & 76.19 & 83.55 & 58.06 & 72.60 \\
\hline $\begin{array}{l}\text { (Binasarisha-5/Daulot)7 } \\
\text { (Binasarisha-5/Daulot)5- }\end{array}$ & 82.88 & 81.81 & 63.09 & 75.92 \\
\hline Binasarisha-5 & 79.42 & 81.81 & 67.18 & 76.13 \\
\hline $\begin{array}{l}\text { (Binasarisha-5/Daulot)5- Daulot } \\
\text { (Binasarisha-5/Daulot)6- }\end{array}$ & 67.92 & 81.11 & 31.48 & 60.17 \\
\hline $\begin{array}{l}\text { (Binasarisha-5/Daulot)7 } \\
\text { (Binasarisha-5/Daulot)6- }\end{array}$ & 76.87 & 94.44 & 87.26 & 86.19 \\
\hline Binasarisha-5 & 79.20 & 94.44 & 87.62 & 87.08 \\
\hline $\begin{array}{l}\text { (Binasarisha-5/Daulot)6- Daulot } \\
\text { (Binasarisha-5/Daulot)7- }\end{array}$ & 59.60 & 85.42 & 79.78 & 74.93 \\
\hline Binasarisha-5 & 82.98 & 100.0 & 89.585 & 90.85 \\
\hline (Binasarisha-5/Daulot)7- Daulot & 80.46 & 86.31 & 72.72 & 79.83 \\
\hline Binasarisha-5(E)- Daulot & 68.05 & 86.31 & 67.77 & 74.04 \\
\hline Average & 76.74 & 82.17 & 77.24 & 78.71 \\
\hline
\end{tabular}

Table 3. Number and proportion of polymorphic bands, gene diversity obtained in different Brassica lines

\begin{tabular}{|c|c|c|c|}
\hline $\begin{array}{l}\text { Introgressed progeny lines/ } \\
\text { Variety }\end{array}$ & $\begin{array}{l}\text { Number of } \\
\text { polymorphic Loci }\end{array}$ & $\begin{array}{l}\text { Proportion of } \\
\text { polymorphic loci (\%) }\end{array}$ & Gene diversity \\
\hline (Binasarisha-5/Daulot)1 & 7 & 30.43 & 0.140 \\
\hline (Binasarisha-5/Daulot)2 & 4 & 17.39 & 0.052 \\
\hline (Binasarisha-5/Daulot)3 & 3 & 13.04 & 0.047 \\
\hline (Binasarisha-5/Daulot)4 & 7 & 30.43 & 0.132 \\
\hline (Binasarisha-5/Daulot)5 & 10 & 43.48 & 0.187 \\
\hline (Binasarisha-5/Daulot)6 & 6 & 26.09 & 0.119 \\
\hline (Binasarisha-5/Daulot)7 & 2 & 8.70 & 0.034 \\
\hline Binasarisha-5 & 5 & 21.74 & 0.081 \\
\hline Daulot & 2 & 8.70 & 0.026 \\
\hline
\end{tabular}


Table 4. Nei's genetic identity (above diagonal) and genetic distance (below diagonal) values among studied Brassica progeny lines

\begin{tabular}{lccccccccc}
\hline $\begin{array}{l}\text { Introgressed } \\
\text { progeny } \\
\text { lines/ Variety }\end{array}$ & E×G 1 & E×G 2 & E×G 3 & E×G 4 & E×G 5 & E×G 6 & E×G 7 & E & G \\
\hline E×G 1 & & & & & & & & & \\
E×G 2 & 0.126 & $* * *$ & 0.915 & 0.925 & 0.847 & 0.839 & 0.771 & 0.790 & 0.633 \\
E×G 3 & 0.235 & 0.088 & $* * *$ & 0.901 & 0.788 & 0.860 & 0.758 & 0.736 & 0.727 \\
E×G 4 & 0.251 & 0.077 & 0.104 & $* * *$ & 0.833 & 0.798 & 0.827 & 0.802 & 0.646 \\
E×G 5 & 0.176 & 0.165 & 0.237 & 0.182 & $* * *$ & 0.758 & 0.690 & 0.751 & 0.508 \\
E×G 6 & 0.262 & 0.174 & 0.150 & 0.225 & 0.275 & $* * *$ & 0.779 & 0.881 & 0.631 \\
E×G 7 & 0.410 & 0.259 & 0.276 & 0.189 & 0.371 & 0.249 & $* * *$ & 0.875 & 0.686 \\
E & 0.310 & 0.234 & 0.305 & 0.220 & 0.285 & 0.126 & 0.132 & $* * *$ & 0.602 \\
G & 0.709 & 0.456 & 0.317 & 0.436 & 0.677 & 0.459 & 0.376 & 0.507 & $* * * *$ \\
\hline
\end{tabular}

$* * * *$ Introgressed progeny lines/ Variety

$\mathbf{E} \times \mathbf{G}=$ Binasarisha-5/Daulot

$\mathbf{E}=$ Binasarisha-5

$\mathbf{G}=$ Daulot

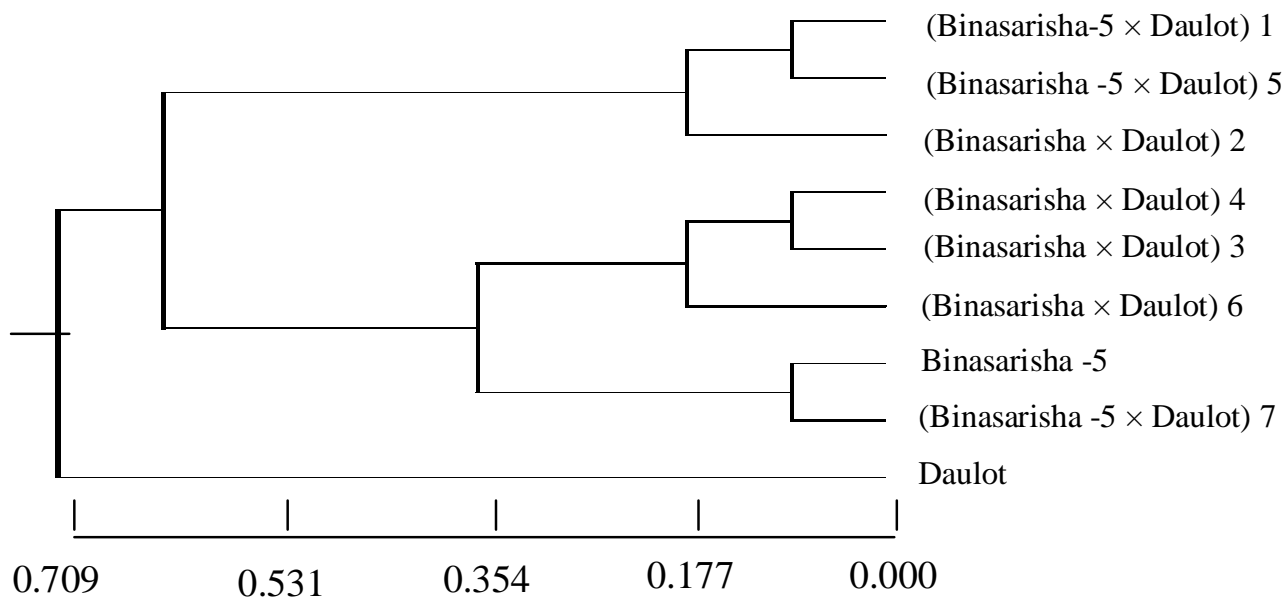

Figure 4. A UPGMA dendrogram based on Nei's (1972) genetic distance, summarizing the data on differentiation between nine Brassica lines according to RAPD analysis

Dendrogram based on Nei's (1972) genetic distance using Unweighted Pair Group Method of Arithemetic Means (UPGMA), the nine accessions were segregated into two major clusters (Fig. 4). As a result, one to seven introgressed progeny lines and Binasarisha-5 
clustered into one group that had two subclusters. Introgressed lines of one, two and five were grouped in sub-cluster I and three, four, six, seven and Binasarisha-5 were grouped in subcluster II. In sub-cluster I, introgressed lines one and five showed closer relationship with minimal genetic distance (0.176). Again sub-cluster II divided into two sub sub-cluster. Introgressed lines three, four and six were grouped in sub subcluster I. Line three and four showed closer relationship with minimal genetic distance (0.104). In sub sub-cluster II, Binasharisha-5 and introgessed line seven clustered into another group and also showed closer relationship with minimal genetic distance (0.132). Daulot, which was $B$. juncea variety and formed one major cluster.

\section{Conclusions}

The present study indicated high level of genetic diversity among the nine accessions and proved that RAPD is an effective molecular marker in differentiating different varieties and introgressed progenies. The results suggest that the introgressed progenies could be used as source for breeding line and improved Brassica varieties. Though, larger number of samples and higher number of primers would be necessary to generate and construct an appropriate genetic relationship, sample identification and analysis of genetic variation among different varieties, cultivars and introgressed progenies is widely acceptable by all concern. Using larger number of samples and higher number of primers could be useful in future research.

\section{Acknowledgement}

Authors express thanks to the DANIDA for supporting this study through the Agriculture Extension Component/ Seed Wing of the Ministry of Agriculture (MoA), Government of the People's Republic of Bangladesh and to Mr. Anwar Faruqe, Joint Secretary MoA and Director-General of the Seed Wing, for his support and keen interest in the project activities.

\section{References}

Carlson, J. E., Tulsieram, L. K., Glubitz, J. C., Luk, V. W. K., Kuffeldt, C. and Tutledge, R. 1991. Segregation of random amplified DNA markers in $F_{1}$ progeny of conifers. Theoretical and Applied Genetics, 83: 194-200.

Chapco, W., Ashton, N. W., Martel, R. K., Antonishishyn, N. and Crosby, W. L. 1992. A feasibility study of the use of random amplified polymorphic DNA in the population genetics and systematic of grasshoppers. Genome, 35: 569-574.

Dan, B., Tu, J. X., Hu, S.Y., He, Y. T., Wang, J. L., Chen, B. Y. and Luan, Y. F. 2003. Analysis of rapeseed germplasm resources in Tibet by RAPD. Acta Agronomica Sinica, 29(1): 1-7.

Das, S., Rajagopal, J., Bhatia, S., Srivastava, P. S. and Lakshmikumaran, M. 1998. Assessment of genetic variation within Brassica campestris cultivars using amplified fragment length polymorphism and random amplification of polymorphic DNA markers. Plant Molecular Biology Division, Tata Energy Research Institute, Darbari Seth Block, Habitat Place, Lodhi Road, New Delhi 110 003, India.

Duan, Y. S., Liu, P. W. and Yang, G. S. 2002. Fingerprinting analysis of the parents of rape hybrids based on RAPD. Chinese Journal of Oil Crop Science, 24(2): 5-9.

Edwards, K. J., 1998. Randomly amplified polymorphic DNAs (RAPDs). In: Molecular Tools for Screening Bindiversity, Karp A, Issac PG and Ingram DS (eds), Chapman and Hall, Cambridge, 171- 175.

Furguth, A., Bartkowiak, I. and Matuszczak, M. 2000. Evaluation of genetic distance among GMS Janpol lines using PCR-RAPD markers. RoslinyOleiste, 21(2): 369-379. 
Geraci, A., Divaret, I., Raimondo, F. M. and Chevre, A. M. 2001. Genetic relationships between Sicilian wild populations of Brassica analyzed with RAPD markers. Plant Breeding, 120(3): 193-196.

Giovannoni, J. J., Wing, R. A., Ganal, N. W. and Tanksley, S. 1991. Isolation of molecular markers from specific chromosomal intervals using DNA pools from existing mapping populations. Nucleic Acids Ressearch, 19: 6553- 6558.

Hallden, C., Hansen, M., Nilsson, N. O., Hejrdin, A. and Sall, T. 1996. Competition as a source of errors in RAPD analysis. Theoretical and Applied Genetics, 93: 1185- 1192.

Lynch, M. 1991. Analysis of population genetic structure by DNA fingerprinting. In: DNA fingerprinting approaches and applications, Burke T, Dolf G, Jeffreys AJ and Wolf R (eds), Basel, Switzerland, 113-126.

Machao, Z., Takako, S., Fu, T.D., Jin, M. L., Yang, G. S. and Tu, J. X. 2003. Genetic diversity of parents for hybrid breeding in Brassica napus L. detected by RAPDs and RFLPs. Acta Agronomica Sinica, 29(5): 701-707.

Mailer, R. J., Scarth, R. and Fristenski, B. 1994. Discrimination among cultivars of rapeseed (Brassica napus L.) using DNA polymorphisms amplified from arbitrary primers. Theoretical and Applied Genetics, 87: 697-704.

Matsui, T., Okuda, N. and Kosugi, Y. 2002. Classification of Chinese kale cultivars by RAPD analysis. Journal of the American Society for Horticultural Science, 71(4): 499-503.

Hasan, M. and Raihan, M. S. 2015. Genetic Variability in Bangladeshi Aromatic Rice through RAPD Analysis. Turkish Journal of Agriculture, Food Science and Technology, 3(3): 107-111.

Hasan, M. and Raihan, M. S. 2014. Genetic Polymorphism in Bangladeshi Aromatic Rice through RAPD Analysis. Journal of Bioscience and Bioengineering,1(2): 2327.

Michelmore, R. W., Paran, I. and Kesseli, R. V. 1991. Identification of markers linked to disease-resistance genes by bulked segregant analysis: a rapid method to detect markers in specific genomic regions by using segregating populations. Proceedings of the National Academy of Sciences, 88: 9828-9832.

Nei, M. 1972. Genetic distance between populations. The American Naturalist, 106: 283-292.

Prakash, S. and Hinata, K. 1980. Taxonomy, cytogenetics and origin of crop Brassica, a review Opera Botany, 55: 1-57.

Qiao, A. M., Liu, P. Y., Lei, J. J., Huang, X. L. and $\mathrm{Fu}$, J. R. 1998. Identification of mustard (Brassica juncea Coss.) cultivars with RAPD markers. Acta Scientiarum Naturalium Universitatis Sunyatseni, 37(2): 73-76.

Rabbani, M. A., Iwabuchi, A., Murakmi, Y., Suzuki, T. and Takayanagi, K. 1998. Genetic diversity in mustard (Brassica juncea L.) germplasm from Pakistan as determined by RAPDs. Euphytica, 103(2): 235-242.

Reiter, R. S., Williams, J. G. K., Feldmann, K. A., Rafalksi, J. A., Tingey, S. V. and Scolnik, P. A. 1992. Global and local genome mapping in Arabidopsis thaliana by using recombinant inbred lines and random amplified polymorphic DNAs. Proceedings of the National Academy of Sciences, 89: 1477-1481. 
Sharma, R., Aggarwal, R. A. K., Kumar, R., Mohapatra, T. and Sharma, R. P. 2002. Construction of an RAPD linkage map and localization of QTLs for oleic acid level using recombinant inbreeds in mustard (Brassica juncea). Genome, 45(3): 467-472.

Tinker, N. A., Fortin, M. G. and Mather, D. E. 1993. Random amplified polymorphic DNA and pedigree relationships in spring barley. Theoretical and Applied Genetetics, 85: 976- 984.

Warwick, S. I. and Mc Donald, T. 2001. Molecular characterization of genetic relationships in Brassica rapa based on RAPD markers, Agril Agri-Food Eastern Cereal and Oilseed Res Centre, K W Neatby Bldg, CEF, Ottawa, Ontario K1A OC6, Canada.
Williams, J. G. K., Kubelik, A. R., Liva, K. J., Rafalski, J. A. and Tingey, S. V. 1990. DNA polymorphisms amplified by arbitrary primer are useful as genetic markers. Nucleic Acids Research, 18(22): 6531-6535.

Yarnell, S. H. 1956. Cytogenetics of Vegetable Crops. The Botanical Review, 22(2): 81166.

Yeh, F. C., Yang, R. C. Boyle, T. B. J., Ye, Z. H. and Mao, J. X. 1999. POPGENE, the user-friendly shareware for population genetic analysis. Molecular Biology and Biotechnological Centre, University Alberta, Canada.

Yuan, M., Zhou, Y. and Liu, D. 2004. Genetic diversity among populations and breeding lines from recurrent selection in Brassica napus as revealed by RAPD markers. Plant Breeding, 123(1): 9-12. 